\title{
Evodiamine Suppresses Survival, Proliferation, Migration and Epithelial-Mesenchymal Transition of Thyroid Carcinoma Cells
}

\author{
SI HYOUNG KIM, JUN GOO KANG, CHUL SIK KIM, SUNG-HEE IHM, MOON GI CHOI and SEONG JIN LEE
}

\author{
Division of Endocrinology and Metabolism, Department of Internal Medicine, \\ College of Medicine, Hallym University, Chuncheon, Republic of Korea
}

\begin{abstract}
Background/Aim: The aim of this study was to evaluate the effect of evodiamine alone or in combination with chemotherapeutic agents on thyroid carcinoma cells. Materials and Methods: TPC-1 and SW1736 thyroid carcinoma cells were used. Cell viability, cytotoxic activity, apoptosis and migration were examined by applying appropriate methods. Drug combination analysis was performed. Results: Evodiamine treatment of cells decreased cell viability, and Bcl2 and phospho-AKT protein levels. Cytotoxic activity and the percentage of apoptotic cells increased. After co-treatment of wortmannin, cell viability, and phospho-AKT and Bcl 2 protein levels decreased, and cytotoxic activity increased. In transforming growth factor- $\beta$-treated cells, evodiamine attenuated variations in morphology, growth and migration, and increased $p 21$ and $p 53$ protein levels, and decreased $\beta$-catenin, $N$-cadherin, vimentin, phospho-AKT, matrix metalloproteinase2 and matrix metalloproteinase-9 protein levels. When cells were treated with both evodiamine and chemotherapeutic agents, all combination index values were lower than 1.0. Conclusion: Evodiamine was cytotoxic towards thyroid carcinoma cells, and repression of AKT reinforced evodiamineinduced cytotoxicity. Furthermore, evodiamine ameliorated proliferation, migration and epithelial-mesenchymal transition, and synergized with chemotherapeutic agents.
\end{abstract}

Well differentiated thyroid cancer (WDTC), including papillary thyroid cancer (PTC) and follicular thyroid cancer (FTC), is the most frequent subtype with excellent outcomes, whereas it is refractory to radioactive iodine (RAI) therapy in approximately two thirds of patients with distant metastasis (1-3). On the other

Correspondence to: Seong Jin Lee, Division of Endocrinology and Metabolism, Department of Internal Medicine, College of Medicine, Hallym University, Chuncheon 200-704, Republic of Korea. Tel: +82 313803700, Fax: +82 313833768, e-mail: leesj@hallym.ac.kr

Key Words: Thyroid carcinoma, evodiamine, AKT, chemotherapeutic agent, synergism. hand, undifferentiated thyroid cancer (UDTC) including anaplastic thyroid cancer (ATC) presents highly aggressive features characterized as extrathyroidal invasion and distant metastasis with disastrous outcomes (1-3). Since patients with RAI therapy-refractory WDTC and UDTC are not responsive to conventional treatment modalities, new therapeutic approaches to improve therapeutic efficacy against cancer cells are under investigation (1-3).

Evodiamine is a natural indole alkaloid isolated from the fruit of Evodia rutaecarpa, also named as Wu-Zhu-Yu, and a multi-target compound possessing a broad spectrum of biological actions (4). Evodiamine has been traditionally used for treatment of abdominal pain, vomiting, diarrhea, headache and postpartum hemorrhage in herbal medicine (4). Evodiamine exerts beneficial activities in thermoregulation, nociception, inflammation, obesity, cardiovascular disease, infectious disease and Alzheimer's disease, and poses antitumor properties in a variety of cancer cells $(4,5)$. It has been proposed that the mechanism of anticancer action of evodiamine is cell cycle arrest at $\mathrm{G}_{2} / \mathrm{M}$ phase through activation of $\mathrm{Cdc} 2 /$ cyclin $\mathrm{B}$ complex, and induction of cell death by modulating survival-related proteins including $\mathrm{Bcl} 2$ family proteins, p21 and p53 as well as multiple signaling pathways including PI3K/AKT and nuclear factor-kappaB (NF-kB) (6-15). However, the influence of evodiamine on survival of thyroid carcinoma cells has not been identified.

Evodiamine attenuates migration, invasion and metastasis of cancer cells, and thereby abrogates cancer progression (5, 16). Evodiamine represses cell migration and invasion via regulation of matrix metalloproteinase-2 (MMP-2) and matrix metalloproteinase-9 (MMP-9) in prostate and nasopharyngeal cancer cells, and reduces formation of metastatic foci in colon cancer animal model (17-19). In regard to epithelialmesenchymal transition (EMT), evodiamine suppresses hepatocyte growth factor (HGF)-activated invasiveness of cancer cells, and abolishes self-renewal through mitigation of EMT in gastric cancer stem cells, and ameliorates transforming growth factor- $\beta$ (TGF- $\beta$ )-activated EMT in in vitro and in vivo models $(15,20-22)$. Meanwhile, evodiamine has cytotoxic activities in breast cancer refractory to 
conventional chemotherapeutic agents $(23,24)$. Furthermore, evodiamine exhibits cytostatic and cytotoxic properties in paclitaxel-resistant ovarian cancer cells (25). However, the combined effect of evodiamine with chemotherapeutic agents on thyroid carcinoma cells has not been explored.

The aim of the present study was to assess the influence of evodiamine on cell survival, proliferation, migration and EMT, and analyze the effect of evodiamine in combination with chemotherapeutic agents on growth and survival in thyroid carcinoma cells. Our results demonstrated that evodiamine has a negative impact on cell survival, proliferation, migration and EMT, and has synergistic action with chemotherapeutic agents in inhibition of growth and survival of thyroid carcinoma cells.

\section{Materials and Methods}

Materials. RPMI1640, fetal bovine serum (FBS), L-glutamine and streptomycin/penicillin were purchased from Life Technologies (Carlsbad, CA, USA). Evodiamine, doxorubicin, paclitaxel and cisplatin were obtained from BioVision (Linda, CA, USA), and dissolved in dimethylsulfoxide (DMSO). Control cells were treated with $0.1 \%$ vehicle DMSO. The primary antibodies against Bcl2, Bax, survivin, phospho-histone H2A.X $(\gamma \mathrm{H} 2 \mathrm{AX})$, cleaved poly (ADPribose) polymerase (PARP), total and phospho-NF-kB (Ser536), total and phospho-c-Jun N-terminal kinase (JNK) (Thr183/Tyr185), total and phospho-extracellular signal-regulated kinase (ERK) $1 / 2$ (Thr402/Tyr404), p21, p53, MMP-2, MMP-9, $\beta$-catenin, N-cadherin, vimentin and slug were purchased from Cell Signaling Biotechnology (Danvers, MA, USA). The primary antibodies against total and phospho-AKT (Ser473) were obtained from Santa Cruz Biotechnology (Santa Cruz, CA, USA), and the primary antibody against $\beta$-actin was from Sigma (St. Louis, MO, USA). All other reagents were purchased from Sigma unless otherwise stated.

Cell culture. For experiments, TPC-1 human PTC cells were obtained from Professor Young Joo Park (Division of Endocrinology and Metabolism, Seoul National University, Republic of Korea), and grown in RPMI1640 supplemented with $10 \%$ heat-inactivated FBS and $1 \%$ streptomycin/penicillin. SW1736 human ATC cells were purchased from Cell Lines Service (CLS GmbH, Eppelheim, Germany), and grown in RPMI1640 supplemented with $2 \mathrm{mM}$ L-glutamine, $10 \%$ heat-inactivated FBS and 1\% streptomycin/ penicillin. Cells received fresh medium at regular intervals. Treatments and experiments were performed using cells that were $70 \%$ confluent.

CCK-8 assay. Cell viability was determined by the CCK- 8 Assay Kit (Dojindo laboratories, Kumamoto, Japan). Cells $\left(5 \times 10^{3} / 100 \mu \mathrm{l}\right)$ in each well on 96-well plates were incubated overnight, and treated with agents for an additional $4 \mathrm{~h}$ at $37^{\circ} \mathrm{C}$. Absorbance was measured using Glomax ${ }^{\mathrm{TM}}$ Discover System GM3000 (Promega, Madison, WI, USA). All experiments were performed in triplicate.

Cytotoxicity assay. Cytotoxic activity was measured by the LDH Cytotoxicity Assay Kit (BioVision, Linda, CA, USA). Cells $\left(5 \times 10^{3} / 100 \mu \mathrm{l}\right)$ in each well on 96 -well plates were incubated, and centrifuged at $250 \mathrm{~g}$ for $10 \mathrm{~min}$. Supernatant of $100 \mu \mathrm{l}$ was transferred in clear 96-well plates. After addition of reaction mixture (2.5 $\mu$ l Catalyst solution in $112.5 \mu \mathrm{l}$ Dye solution), cells were incubated for $30 \mathrm{~min}$ at room temperature. Absorbance was measured using Glomax ${ }^{\mathrm{TM}}$ Discover System GM3000 (Promega). All experiments were performed in triplicate.

FACS analysis. Apoptotic cells were analyzed by the Annexin V-FITC Apoptosis Detection Kit (BD Biosciences Pharminogen, San Diego, CA, USA). Cells $\left(1 \times 10^{5} / \mathrm{ml}\right)$ in each well on 6-well plates were incubated, harvested, washed, and fixed according to manufacturer's protocol. FITC annexin $\mathrm{V}$ and/or propidium iodide (PI) in $1 \times$ binding buffer was added for $15 \mathrm{~min}$ at room temperature, and analysis was made using a CytoFLEX ${ }^{\mathrm{TM}}$ Flow Cytometer (Beckman Coulter Inc., Brea, CA, USA) and CytExpert Software (Beckman Coulter Inc., Brea, CA, USA). All experiments were performed in triplicate.

Cell number count. Cell growth was determined by cell number count using trypan blue. Cells $\left(1 \times 10^{5 / 500 \mu l)}\right.$ in each well on 12 well plates were incubated, and mixed with trypan blue dye at $37^{\circ} \mathrm{C}$. Stained cells were counted using a hemocytometer. All experiments were performed in triplicate.

Wound healing assay. Cell migration was measured by the CytoSelect $^{\mathrm{TM}}$ 24-Well Wound Healing Assay Kit (Cell Biolabs, San Diego, CA, USA). Following generation of a wound field $(0.9 \mathrm{~mm})$, cells were incubated, and treated at $37^{\circ} \mathrm{C}$. The wound closure was monitored by light microscope, and the cell migration rate was calculated according to the following equation: cell migration= [length of cell migration (nm)/migration time (h)]. All experiments were performed in triplicate.

Western blotting. The total protein was extracted by RIPA buffer (Sigma) containing $1 \times$ protease inhibitor cocktail and $1 \times$ phosphatase inhibitor cocktail set V (Calbiochem, La Jolla, CA, USA). Western blotting was performed using specific primary antibodies and horseradish peroxidase-conjugated anti-rabbit and anti-mouse secondary antibodies. Bands were detected using ECL Plus Western Blotting Detection System (Thermo Fisher Scientific, Rockford, IL, USA). The protein levels were quantified by densitometry using ImageJ software (NIH), and normalized to $\beta$-actin levels. The relative levels of protein to $\beta$-actin were obtained. All experiments were performed in triplicate.

Drug combination analysis. Combination index (CI) and isobologram were calculated by CalcuSyn program version 2.11 (Biosoft, Great Shelford, Cambridge, UK), and the effect of drug interactions was quantitatively documented. CI values less than 1.0,1.0 and greater than 1.0 manifest synergism, additivity and antagonism, respectively. The isobologram is formed by plotting the doses of each agent required for $50 \%$ inhibition $\left(\mathrm{ED}_{50}\right)$ on the $\mathrm{x}$ - and $\mathrm{y}$-axis, and connecting them to draw a line segment, which is $\mathrm{ED}_{50}$ isobologram. Combination data points that fall on, below and above the line segment manifest additivity, synergism and antagonism, respectively. All combinations were performed in triplicate.

Statistical analysis. All data are expressed as mean \pm standard error (S.E). Data were analyzed by unpaired Student's $t$-test or ANOVA as appropriate. A $p$-value less than 0.05 was considered to indicate statistical significance. All analyses were performed using SPSS program version 24.0 (SPSS, Chicago, IL, USA). 

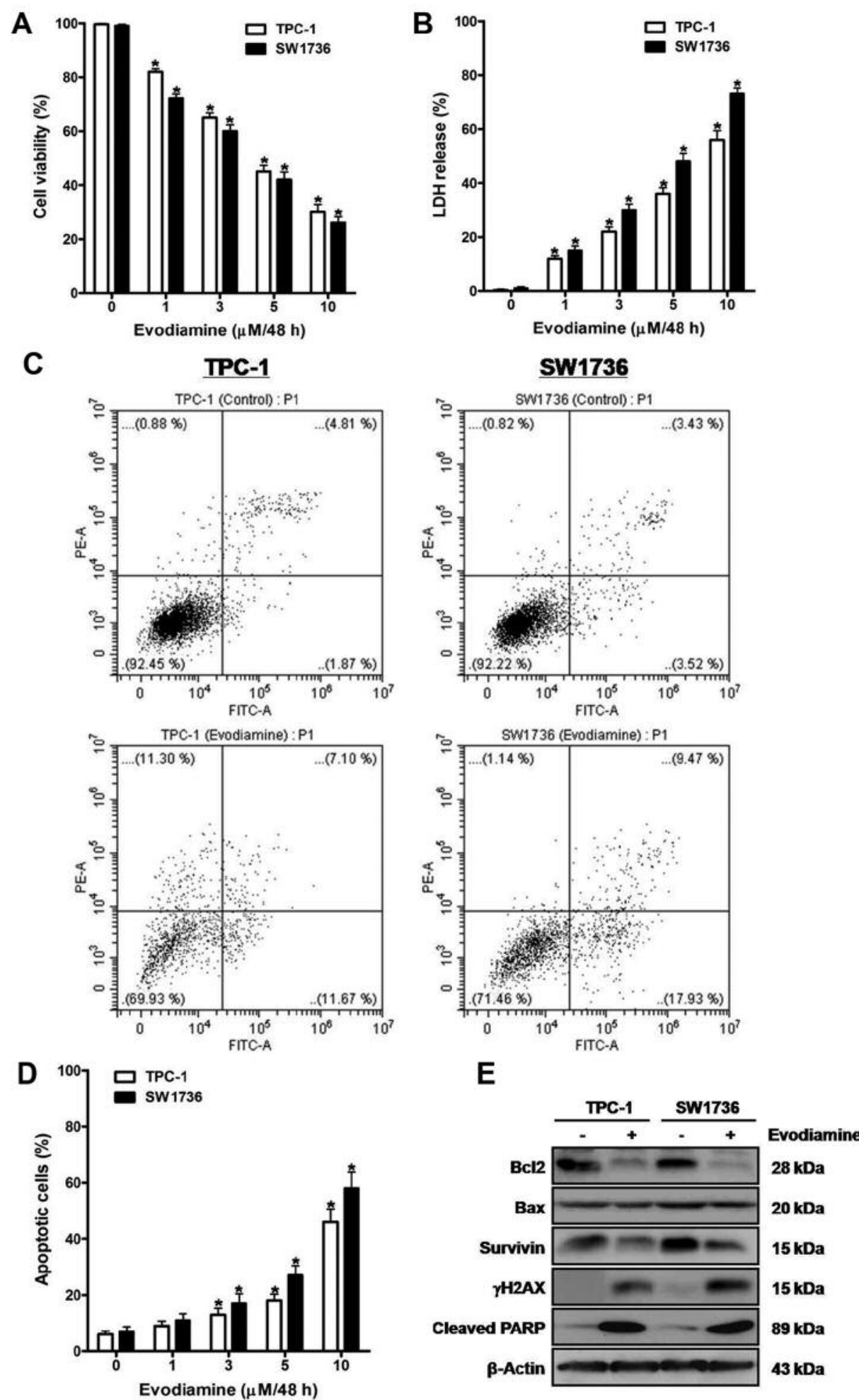

Figure 1. The effect of evodiamine on survival of thyroid carcinoma cells. TPC-1 and SW1736 cells were treated with 1, 3, 5 and $10 \mu M$ evodiamine for $48 \mathrm{~h}$, and cell viability $(A)$ and cytotoxic activity $(B)$ were measured using CCK-8 assay and cytotoxicity assay, respectively. C: TPC-1 and SW1736 cells were treated with $5 \mu M$ evodiamine for $48 \mathrm{~h}$, and then the percentage of apoptotic cells was measured using FACS analysis. D: TPC-1 and SW1736 cells were treated with 1, 3, 5 and $10 \mu \mathrm{M}$ evodiamine for $48 \mathrm{~h}$, after which the percentage of apoptotic cells was measured. E: TPC-1 and SW1736 cells were treated with $5 \mu M$ evodiamine for $48 \mathrm{~h}$, and the protein levels of Bcl2, Bax, survivin, $\gamma H 2 A X$ and cleaved PARP were measured. All experiments were performed in triplicate. The blots are representative of three independent experiments. Data are expressed as mean $\pm S . E$. ${ }^{*} p<0.05 \mathrm{vs.}$ each matched control. 
A Evodiamine (h/5 $\mu \mathrm{M})$ Evodiamine ( $\mu \mathrm{M} / 48 \mathrm{~h})$
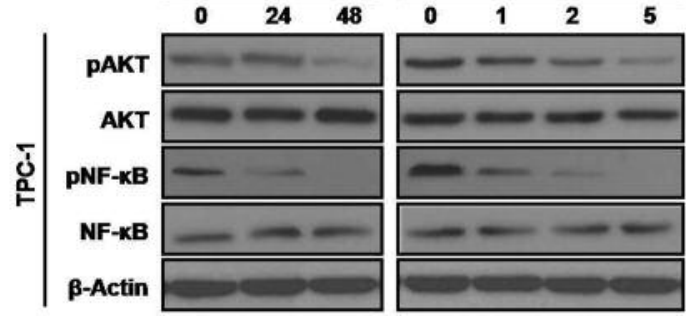

$60 \mathrm{kDa}$

$60 \mathrm{kDa}$

$65 \mathrm{kDa}$

$65 \mathrm{kDa}$

$43 \mathrm{kDa}$
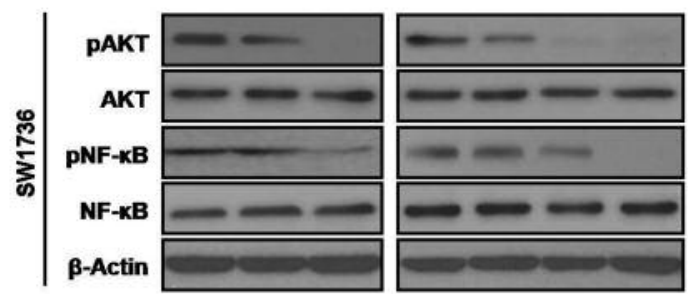

$60 \mathrm{kDa}$

$60 \mathrm{kDa}$

$65 \mathrm{kDa}$

$65 \mathrm{kDa}$

$43 \mathrm{kDa}$

C

TPC-1

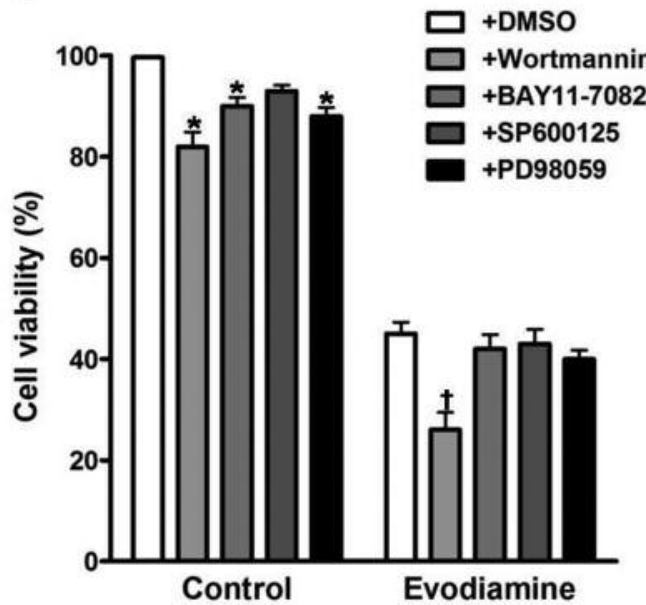

D

TPC-1

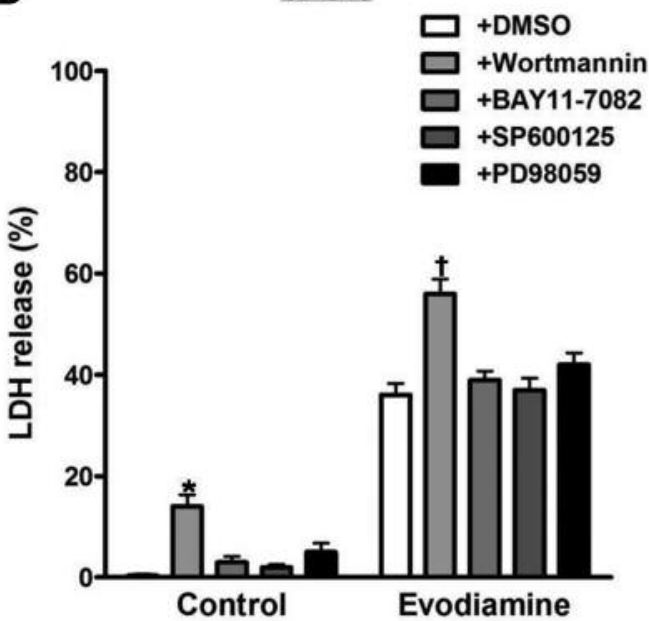

B

Evodiamine (h/5 $\mu \mathrm{M})$ Evodiamine ( $\mu \mathrm{M} / 48 \mathrm{~h})$
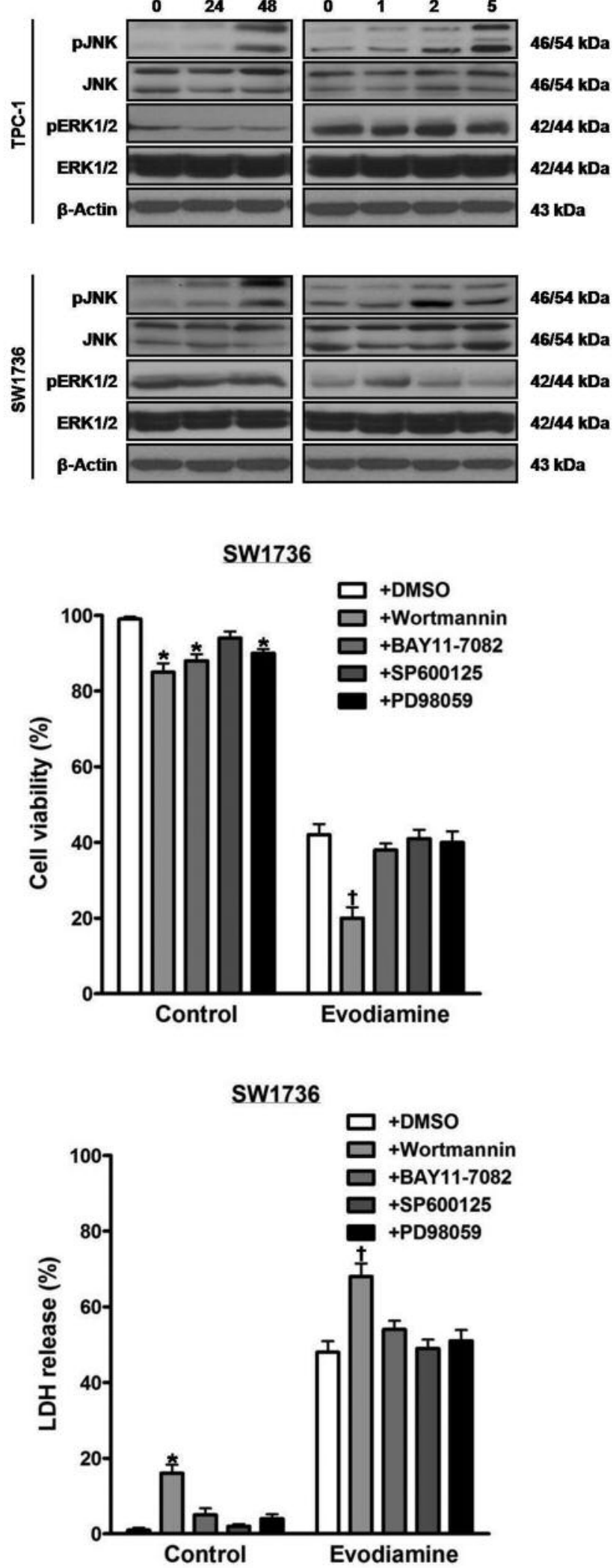

Figure 2. Continued 

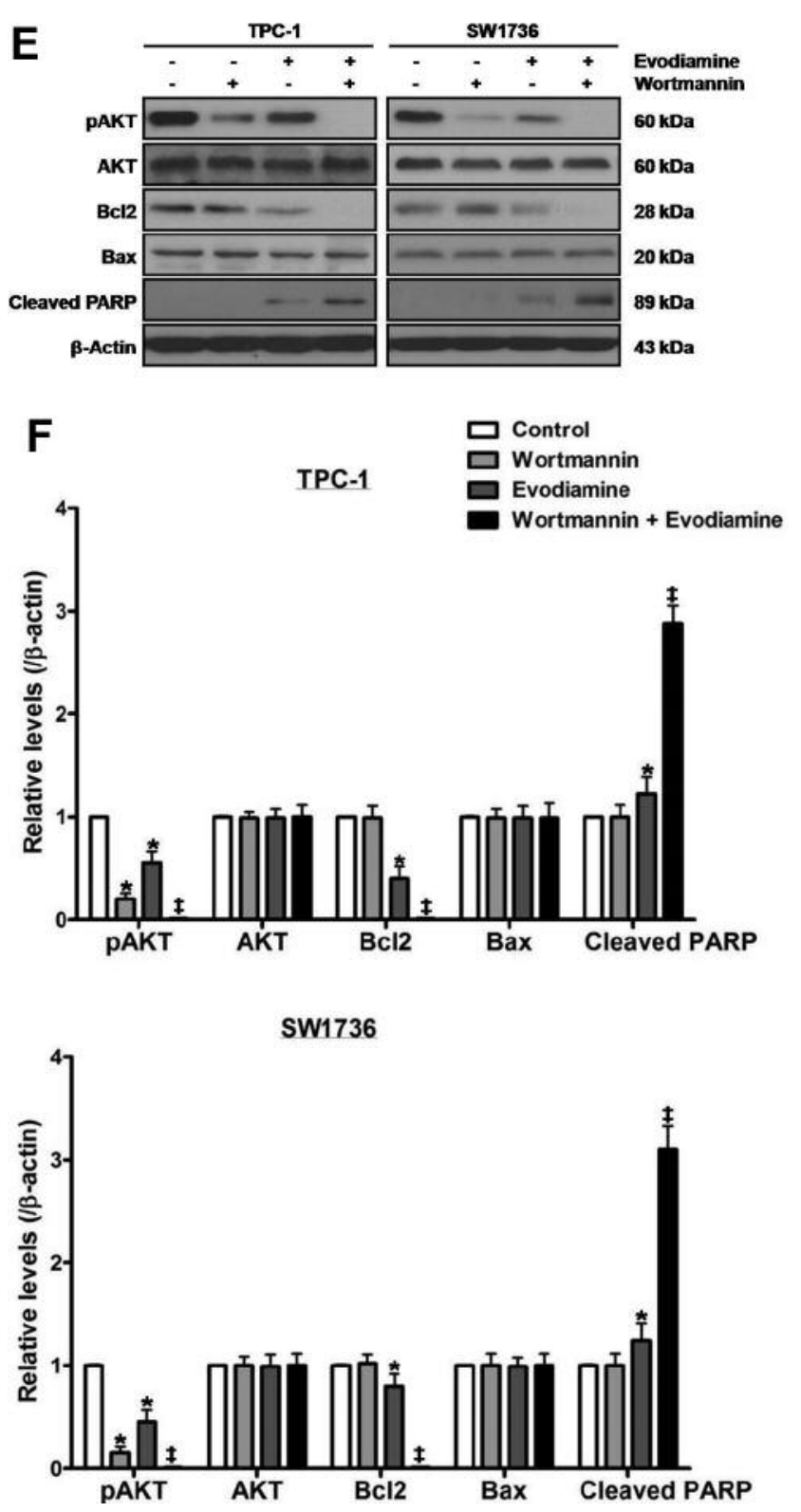

Figure 2. The influence of evodiamine on signal proteins in thyroid carcinoma cells. TPC-1 and SW1736 cells were treated with $5 \mu M$ evodiamine for 24 and $48 \mathrm{~h}$, and 1,2, and $5 \mu \mathrm{M}$ for $48 \mathrm{~h}$, and the total and phospho-protein levels of AKT and NF-kB $(A)$ as well as those of JNK and ERK1/2 (B) were measured. TPC-1 and SW1736 cells were treated with $2 \mu M$ of the PI3K inhibitor wortmannin, $0.2 \mu M$ of the $N F-x B$ inhibitor BAY11-7082, $2 \mu M$ of the JNK inhibitor SP600125 or $2 \mu M$ of the MEK inhibitor PD98059 prior to treatment with $5 \mu M$ evodiamine for $48 \mathrm{~h}$, and then cell viability $(C)$ and cytotoxic activity $(D)$ were measured. $E$ and $F$ : $T P C-1$ and SW1736 cells were treated with $2 \mu M$ wortmannin before treatment with $5 \mu M$ evodiamine for 48 h, after which the protein levels of total and phospho-AKT, Bcl2, Bax and cleaved PARP were measured, and quantified by densitometry, and normalized to $\beta$-actin levels. All experiments were performed in triplicate. The blots are representative of three independent experiments. Data are expressed as mean $\pm S . E .{ }^{*} p<0.05$ $v s$. each matched control; ${ }^{\dagger} p<0.05$ vs. cells treated with both evodiamine and DMSO; ${ }^{+} p<0.05$ vs. cells treated with evodiamine alone.

\section{Results}

Evodiamine induces death of thyroid carcinoma cells. To evaluate the effect of evodiamine on cell survival, TPC-1 and SW1736 cells were treated with $1,3,5$ and $10 \mu \mathrm{M}$ evodiamine for $48 \mathrm{~h}$, and then cell viability (Figure 1A) and cytotoxic activity (Figure 1B) were measured using the CCK8 and cytotoxicity assays, respectively. Following treatment, cell viability was diminished, and cytotoxic activity was enhanced in a dose-dependent manner.

When cells were treated with $5 \mu \mathrm{M}$ evodiamine for $48 \mathrm{~h}$, the percentage of apoptotic cells using FACS analysis was enhanced (Figure 1C). Furthermore, treatment of cells with 1, 3,5 and $10 \mu \mathrm{M}$ evodiamine for $48 \mathrm{~h}$ enhanced the percentage of apoptotic cells in a dose-dependent manner (Figure 1D).

To estimate the influence of evodiamine on the expression of survival-related proteins, extracts of cells treated with $5 \mu \mathrm{M}$ evodiamine for $48 \mathrm{~h}$ were examined by western blot using antibodies against $\mathrm{Bcl} 2, \mathrm{Bax}$, survivin, $\gamma \mathrm{H} 2 \mathrm{AX}$ and cleaved PARP (Figure 1E). After treatment, the protein levels of $\gamma \mathrm{H} 2 \mathrm{AX}$ and cleaved PARP were enhanced, and those of $\mathrm{Bcl} 2$ and survivin were diminished without alteration in Bax protein levels.

Inactivation of AKT intensifies evodiamine-induced death of thyroid carcinoma cells. In order to determine the impact of evodiamine on signal proteins, extracts of cells treated with $5 \mu \mathrm{M}$ evodiamine for 24 and $48 \mathrm{~h}$, and 1,2 , and $5 \mu \mathrm{M}$ for $48 \mathrm{~h}$ were examined by western blot using antibodies against total and phosphorylated AKT, NF-kB, JNK and ERK1/2 (Figure 2A and B). Following treatment, the protein levels of phospho-JNK increased, and those of phospho-AKT and phospho-NF-kB decreased. By contrast, the protein levels of total AKT, total NF-kB, total JNK, and total and phosphoERK1/2 were not changed.

To document the roles of signal proteins in survival of cells exposed to $5 \mu \mathrm{M}$ evodiamine for $48 \mathrm{~h}$, cells were pretreated with the PI3K inhibitor wortmannin, the NF-kB inhibitor BAY11-7082, the JNK inhibitor SP600125 or the MEK inhibitor PD98059. After treatment, cell viability (Figure 2C) and cytotoxic activity (Figure 2D) were measured. Wortmannin, but not BAY11-7082, SP600125 and PD98059, decreased cell viability, and increased cytotoxic activity.

When cells were incubated with wortmannin prior to treatment with $5 \mu \mathrm{M}$ evodiamine for $48 \mathrm{~h}$, the protein levels of cleaved PARP increased, and those of phospho-AKT and $\mathrm{Bcl} 2$ decreased. The protein levels of total AKT and Bax in cells treated with both wortmannin and evodiamine were not affected, compared with those in cells treated with evodiamine alone (Figure 2E and F).

Evodiamine suppresses proliferation and migration of thyroid carcinoma cells. To identify the effect of evodiamine on cell 

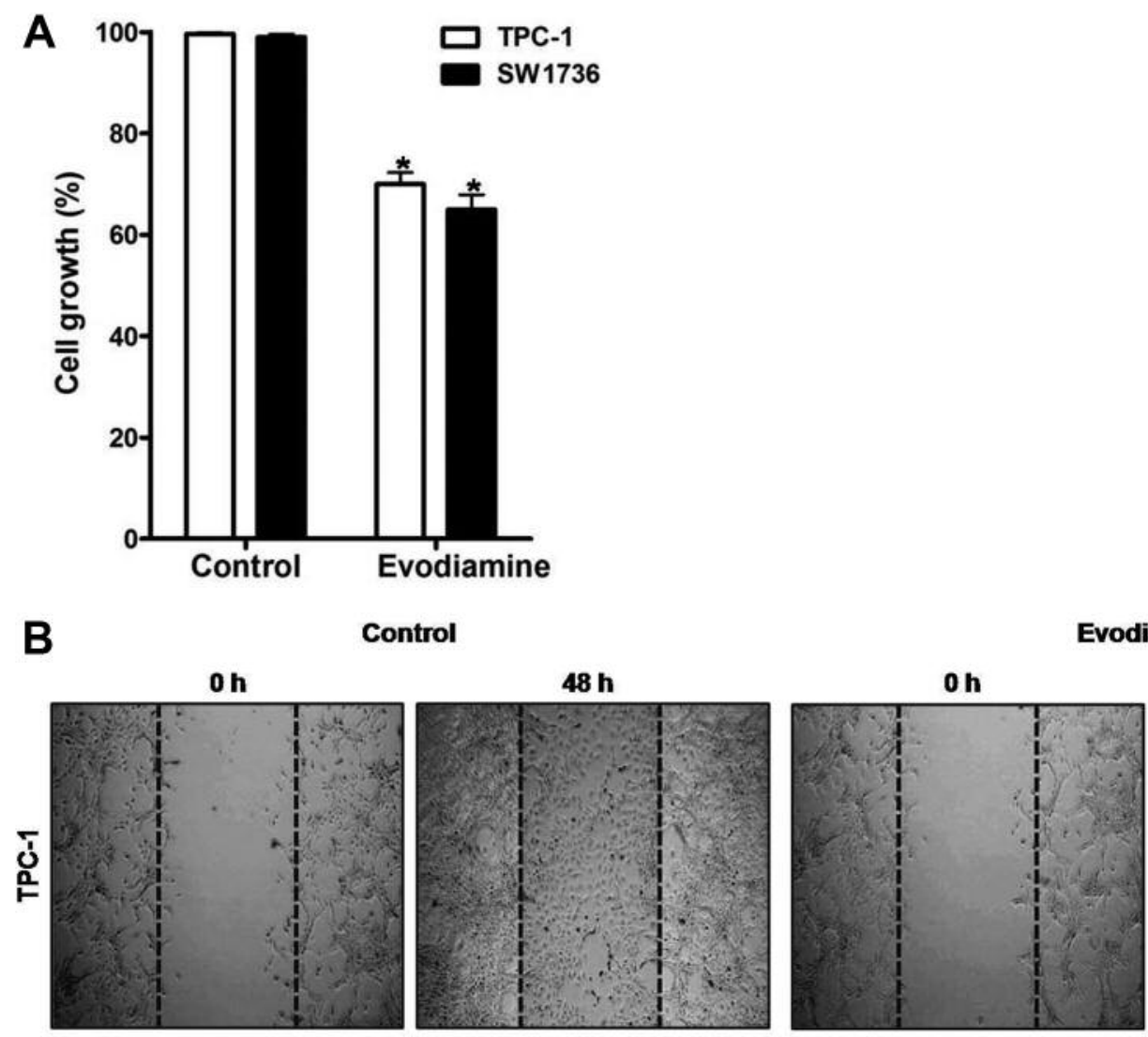

Evodiamine
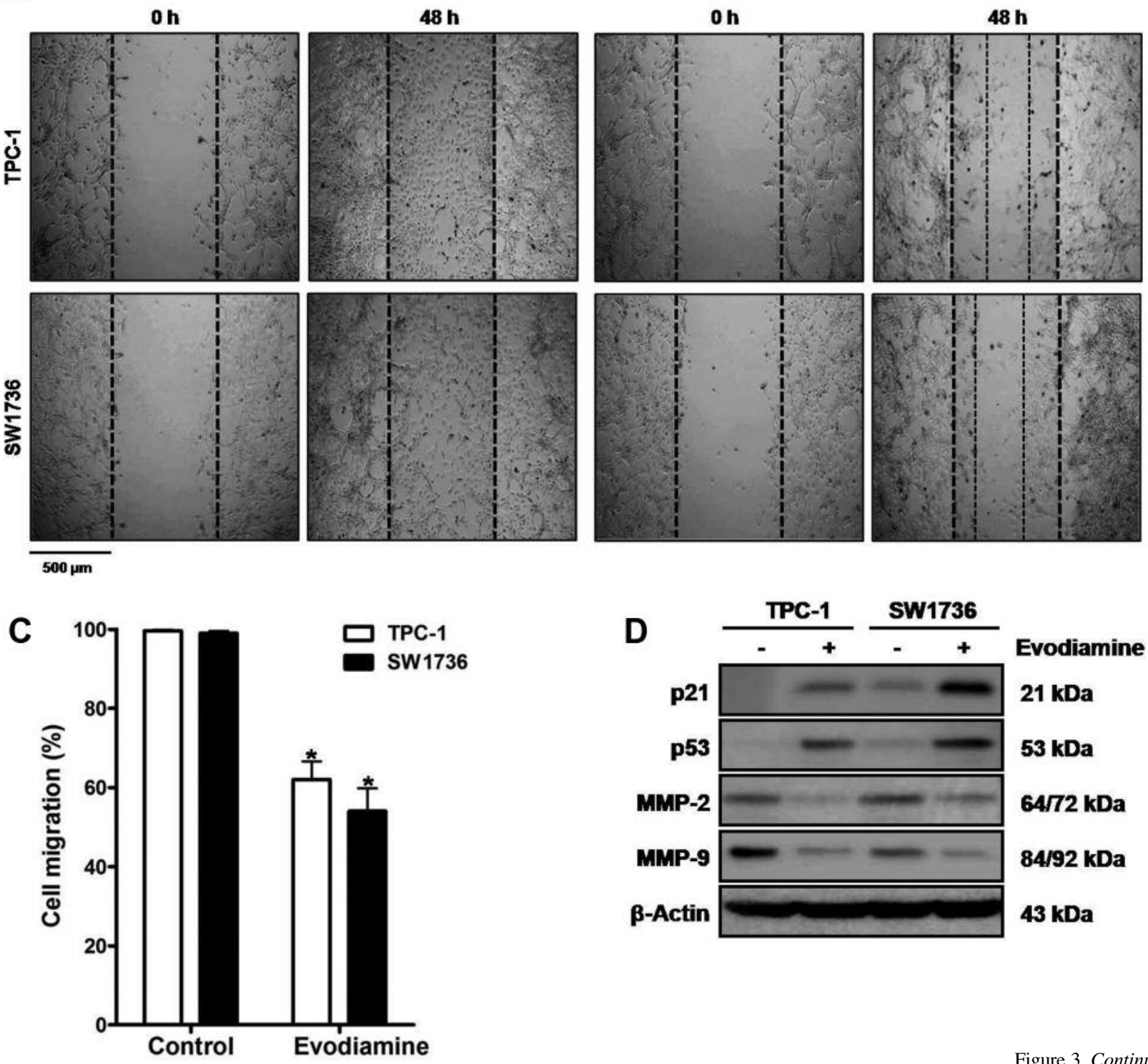

Figure 3. Continued 

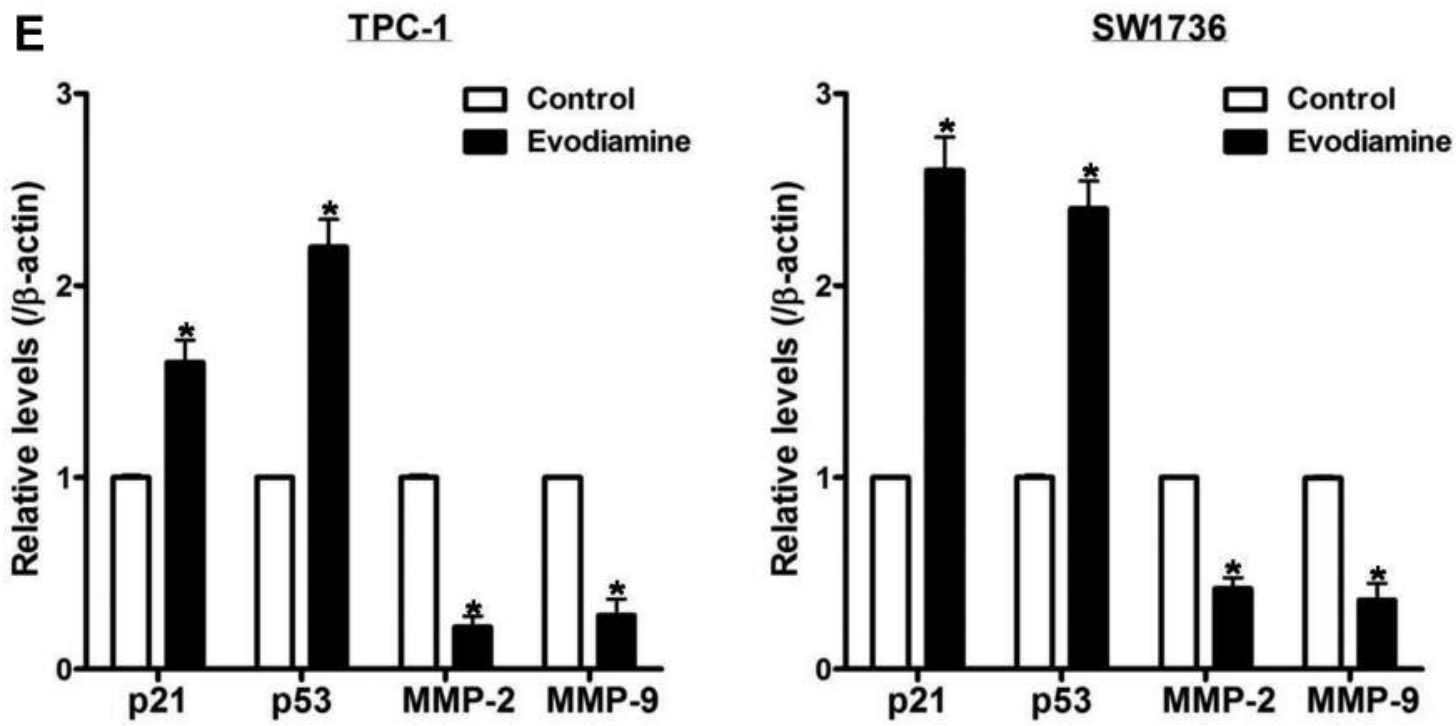

Figure 3. The impact of evodiamine on proliferation and migration of thyroid carcinoma cells. A: TPC-1 and SW1736 cells were treated with $5 \mu M$ evodiamine for $48 \mathrm{~h}$, and cell growth was assayed using cell number count. B and C: TPC-1 and SW1736 cells were treated with $5 \mu M$ evodiamine for $48 \mathrm{~h}$, and then cell migration was measured using wound healing assay. D and E: TPC-1 and SW1736 cells were treated with $5 \mu M$ evodiamine for 48 h, after which the protein levels of $p 21, p 53, M M P-2$ and MMP-9 were measured, and quantified by densitometry, and normalized to $\beta$-actin levels. All experiments were performed in triplicate. The blots are representative of three independent experiments. Data are expressed as mean $\pm S . E$. ${ }^{*} p<0.05$ vs. each matched control.

proliferation, cells were treated with $5 \mu \mathrm{M}$ evodiamine for $48 \mathrm{~h}$, and then cell growth was evaluated by using cell number count (Figure 3A). Cell growth was reduced following treatment with evodiamine.

To inspect the influence of evodiamine on cell migration, cells were treated with $5 \mu \mathrm{M}$ evodiamine for $48 \mathrm{~h}$, and cell migration was estimated using wound healing assay (Figure $3 \mathrm{~B}$ and $\mathrm{C}$ ), and the protein levels of $\mathrm{p} 21, \mathrm{p} 53, \mathrm{MMP}-2$ and MMP-9 (Figure 3D and E) were examined by western blot. After treatment, cell migration and the protein levels of MMP-2 and MMP-9 were reduced, while protein levels of p21 and p53 were elevated.

Evodiamine mitigates TGF- $\beta$-activated EMT in thyroid carcinoma cells. Evodiamine ameliorates cancer progression by alleviating migration, invasion and metastasis of cancer cells $(5,16)$. In this respect, evodiamine interrupts cell migration and invasion through modulation of MMP-2 and MMP-9 in prostate and nasopharyngeal cancer cells, and inhibits formation of metastatic lesions in colon cancer mice model (17-19). With regard to EMT, evodiamine attenuates HGF-induced invasiveness in melanoma, lung and colon cancer cells, and abrogates self-renewal via repression of EMT in gastric cancer stem cells $(15,20)$. Moreover, evodiamine impedes TGF- $\beta$-induced EMT in NRK52E cells and liver fibrosis in rats $(21,22)$. Thus, we examined whether evodiamine affects TGF- $\beta$-stimulated EMT in thyroid carcinoma cells.

To explore the impact of evodiamine on TGF- $\beta$-stimulated EMT, cells were treated with both $5 \mu \mathrm{M}$ evodiamine and 100 $\mathrm{ng} / \mathrm{ml} \mathrm{TGF}-\beta$ for $48 \mathrm{~h}$, and then cell growth (Figure $4 \mathrm{~A}$ ), morphology (Figure 4B) and migration (Figure 4C) were measured. Following treatment, TGF- $\beta$ raised cell growth and migration, and resulted in fibroblast-like phenotype. Evodiamine abolished the TGF- $\beta$-induced alterations in cell growth, morphology and migration.

Treatment of cells with $100 \mathrm{ng} / \mathrm{ml}$ TGF- $\beta$ for $48 \mathrm{~h}$ enhanced the protein levels of N-cadherin, phospho-AKT and MMP-2, and diminished those of p21 and p53 without affecting those of $\beta$-catenin, vimentin, slug, total AKT and MMP-9 (Figure 4D$\mathrm{G})$. Treatment of cells with both evodiamine and TGF- $\beta$, compared with TGF- $\beta$-treated cells, enhanced the protein levels of p21 and p53, and diminished those of $\beta$-catenin, $N$-cadherin, vimentin, phospho-AKT, MMP-2 and MMP-9 without affecting those of slug and total AKT.

Evodiamine synergizes with chemotherapeutic agents in exerting cytostatic and cytotoxic effects on thyroid carcinoma cells. To assess the cytostatic effect of the combination of evodiamine with chemotherapeutic agents, cells were treated with both evodiamine and doxorubicin, paclitaxel or cisplatin, and then the interactions were interpreted by obtaining CI 

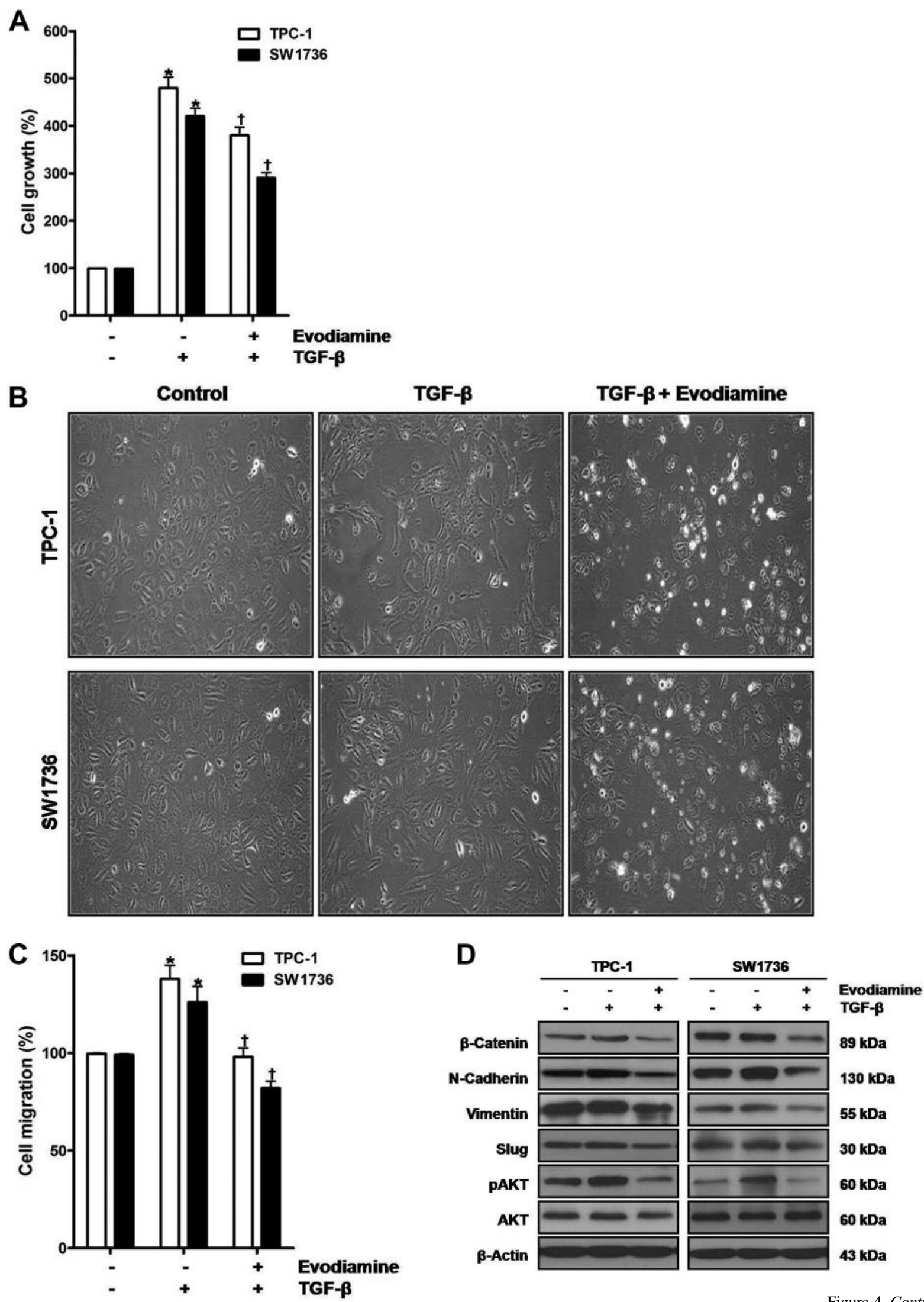

Figure 4. Continued 

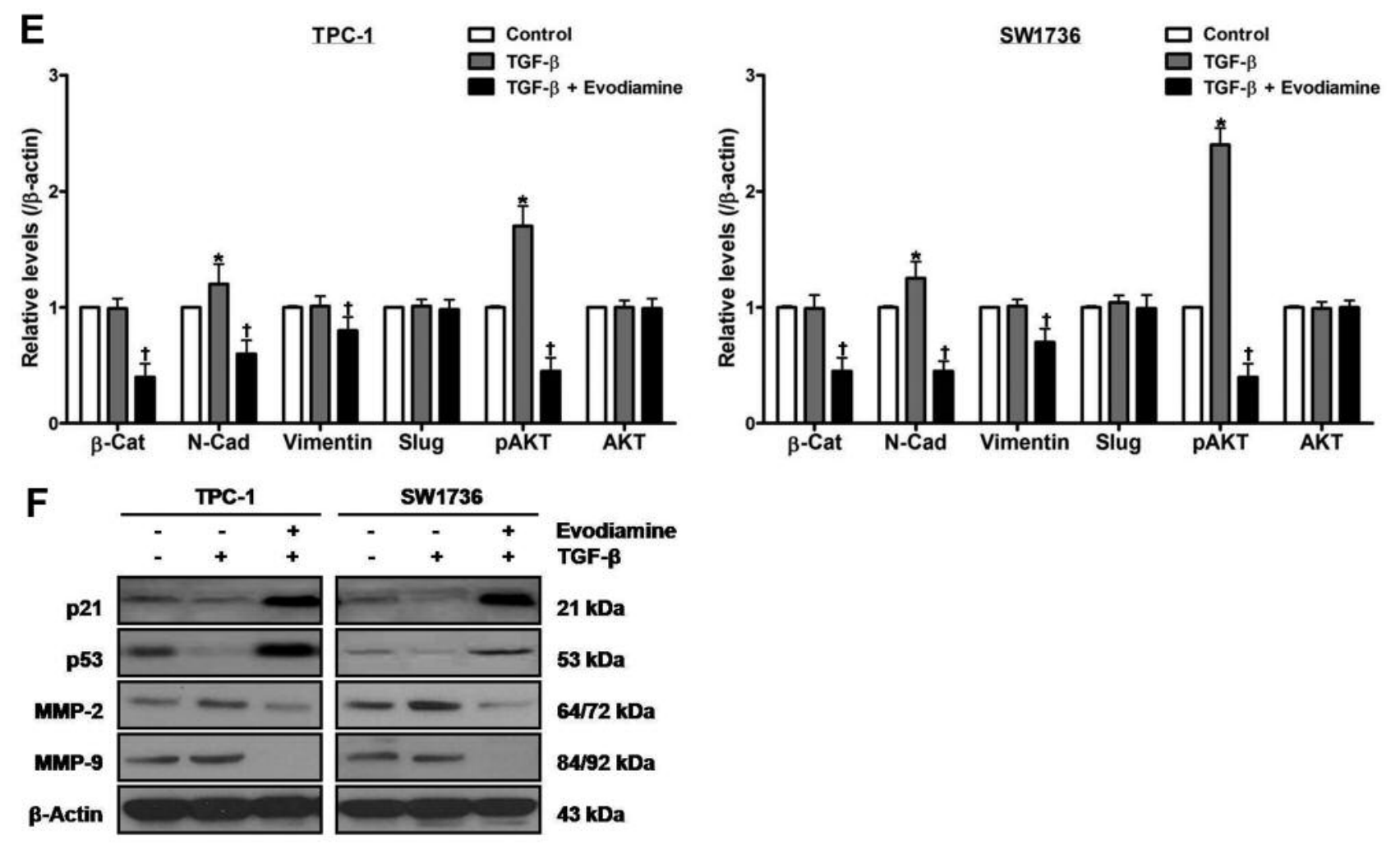

G

TPC-1

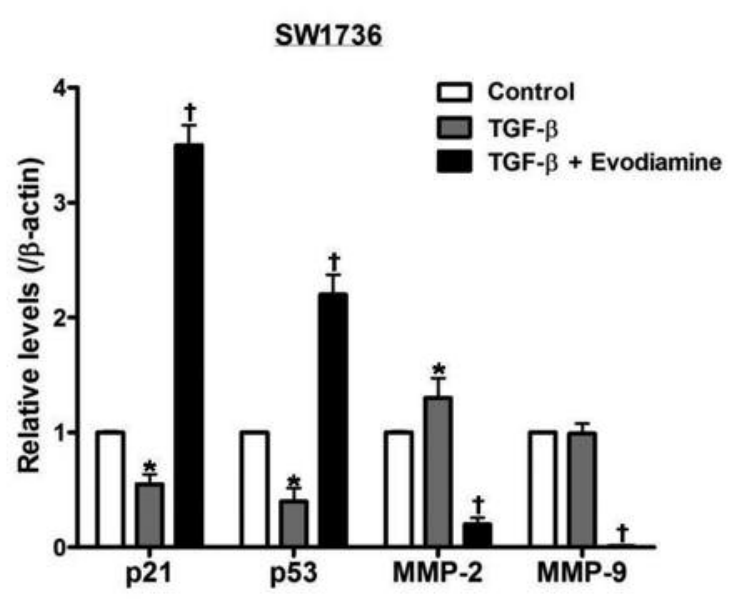

Figure 4. The effect of evodiamine on TGF- $\beta$-stimulated epithelial-mesenchymal transition in thyroid carcinoma cells. TPC-1 and SW1736 cells were treated with both $5 \mu \mathrm{M}$ evodiamine and $100 \mathrm{ng} / \mathrm{ml} T G F-\beta$ for $48 \mathrm{~h}$, and cell growth $(A)$, morphology $(B)$ and migration $(C)$ were measured. $D$ and E: TPC-1 and SW1736 cells were treated with both $5 \mu \mathrm{M}$ evodiamine and $100 \mathrm{ng} / \mathrm{ml}$ TGF- $\beta$ for $48 \mathrm{~h}$, and then the protein levels of $\beta$-catenin, $N$-cadherin, vimentin, slug, and total and phospho-AKT were measured. F and G: TPC-1 and SW1736 cells were treated with both $5 \mu M$ evodiamine and $100 \mathrm{ng} / \mathrm{ml}$ TGF- $\beta$ for $48 \mathrm{~h}$, after which the protein levels of $\mathrm{p} 21$, p53, MMP-2 and MMP-9 were measured. All experiments were performed in triplicate. The blots are representative of three independent experiments. Data are expressed as mean $\pm S . E . * p<0.05 v s$. each matched control; ${ }^{\dagger} p<0.05$ vs. cells treated with both evodiamine and TGF- $\beta$. $\beta$-Cat: $\beta$-Catenin; $N$-Cad: $N$-Cadherin.

using Chou-Talalay equation, where $\mathrm{CI}<1.0$ indicates synergism, and $\mathrm{CI}=1.0$ indicates additivity, and $\mathrm{CI}>1.0$ indicates antagonism (Figure 5A and B, Table I). Cell growth was assayed by using cell number count, and the inhibition rate was computed as 100-cell growth (\%). Following cotreatment, all CI values were lower than 1.0 , and the combination data points were all located below the isobologram line at $\mathrm{ED}_{50}$, suggesting the synergism between evodiamine and chemotherapeutic agents in leading to cytostatic activity in thyroid carcinoma cells. 
Table I. Combination index values of growth of thyroid carcinoma cells at combined doses determined by the median effect analysis method.

\begin{tabular}{|c|c|c|c|c|c|c|c|}
\hline \multirow[t]{2}{*}{ Cells } & \multirow[t]{2}{*}{ Evo $(\mu \mathrm{M})$} & \multirow[t]{2}{*}{$\operatorname{Dox}(\mu \mathrm{M})$} & \multirow[t]{2}{*}{$\mathrm{Pac}(\mathrm{nM})$} & \multirow[t]{2}{*}{ Cis $(\mu \mathrm{M})$} & \multicolumn{3}{|c|}{ CI } \\
\hline & & & & & Evo+Dox & Evo+Pac & Evo+Cis \\
\hline \multirow[t]{4}{*}{ TPC-1 } & 0.5 & 0.5 & 0.5 & 50 & 0.740 & 0.808 & 0.687 \\
\hline & 1 & 1 & 1 & 100 & 0.891 & 0.908 & 0.873 \\
\hline & 1.5 & 1.5 & 1.5 & 150 & 0.786 & 0.842 & 0.874 \\
\hline & 2 & 2 & 2 & 200 & 0.593 & 0.748 & 0.839 \\
\hline \multirow[t]{4}{*}{ SW1736 } & 0.5 & 0.5 & 0.5 & 50 & 0.937 & 0.939 & 0.806 \\
\hline & 1 & 1 & 1 & 100 & 0.769 & 0.876 & 0.813 \\
\hline & 1.5 & 1.5 & 1.5 & 150 & 0.810 & 0.890 & 0.798 \\
\hline & 2 & 2 & 2 & 200 & 0.637 & 0.766 & 0.760 \\
\hline
\end{tabular}

CI: Combination index; Evo: evodiamine; Dox: doxorubicin; Pac: paclitaxel; Cis: cisplatin.

Table II. Combination index values of survival of thyroid carcinoma cells at combined doses determined by the median effect analysis method.

\begin{tabular}{|c|c|c|c|c|c|c|c|}
\hline \multirow[t]{2}{*}{ Cells } & \multirow[t]{2}{*}{ Evo $(\mu \mathrm{M})$} & \multirow[t]{2}{*}{$\operatorname{Dox}(\mu \mathrm{M})$} & \multirow[t]{2}{*}{ Pac (nM) } & \multirow[t]{2}{*}{ Cis $(\mu \mathrm{M})$} & \multicolumn{3}{|c|}{$\mathrm{CI}$} \\
\hline & & & & & Evo+Dox & Evo+Pac & Evo+Cis \\
\hline \multirow[t]{4}{*}{ TPC-1 } & 0.5 & 0.5 & 0.5 & 50 & 0.793 & 0.812 & 0.727 \\
\hline & 1 & 1 & 1 & 100 & 0.901 & 0.883 & 0.880 \\
\hline & 1.5 & 1.5 & 1.5 & 150 & 0.845 & 0.920 & 0.938 \\
\hline & 2 & 2 & 2 & 200 & 0.732 & 0.899 & 0.910 \\
\hline \multirow[t]{4}{*}{ SW1736 } & 0.5 & 0.5 & 0.5 & 50 & 0.851 & 0.851 & 0.905 \\
\hline & 1 & 1 & 1 & 100 & 0.905 & 0.900 & 0.841 \\
\hline & 1.5 & 1.5 & 1.5 & 150 & 0.869 & 0.918 & 0.896 \\
\hline & 2 & 2 & 2 & 200 & 0.797 & 0.833 & 0.843 \\
\hline
\end{tabular}

CI: Combination index; Evo: evodiamine; Dox: doxorubicin; Pac: paclitaxel; Cis: cisplatin.

Next, to analyze the cytotoxic effect of the combination of evodiamine with chemotherapeutic agents, cells were treated with both evodiamine and the above chemotherapeutic agents (Figure 5C and D, Table II). Cell viability was measured using CCK-8 assay, and the death rate was calculated as $100-$ cell viability (\%). After cotreatment, all CI values were lower than 1.0, and the combination data points were all placed below the isobologram line at $\mathrm{ED}_{50}$, implying that evodiamine synergistically has a cytotoxic effect with chemotherapeutic agents in thyroid carcinoma cells.

\section{Discussion}

This study demonstrated, for the first time, that evodiamine resulted in cell death with concomitant variations in survivalrelated proteins, and inactivation of AKT potentiated the negative effect of evodiamine on survival of thyroid carcinoma cells. Additionally, evodiamine attenuated proliferation, migration and EMT by modulating EMT-related proteins, and displayed synergism with chemotherapeutic agents in repressing the growth and survival of thyroid carcinoma cells.
Evodiamine shows remarkable antimitogenic action in a range of cancers including hormone-sensitive prostate and breast cancers on the cellular level (5). As one of feasible mechanisms, it has been reported that evodiamine blocks cell cycle progression at $\mathrm{G}_{2} / \mathrm{M}$ phase in conjunction with stimulation of $\mathrm{Cdc} 2 /$ cyclin B complex $(6,7)$. Meanwhile, Bcl2 family proteins perform multiple crucial functions for cellular homeostasis such as survival and proliferation (26). In this regard, relative expression of the pro-survival protein $\mathrm{Bcl} 2$ and the anti-survival protein Bax, called the Bcl2/Bax switch, has an influence on the survival of cancer cells (27). With respect to impact of evodiamine on survival-related proteins including $\mathrm{Bcl} 2$ family proteins, evodiamine causes cell death through suppression of Bcl2, Bcl-xL, survivin, inhibitor of apoptosis protein, MMP-9, cyclin D1 and cyclooxygenase 2 in a variety of cancer cells (8). Moreover, it has been shown that evodiamine leads to cell death via $\mathrm{Bcl} 2$ regulated by ubiquitin-proteasome system, Bcl2/Bax ratio, p21 and p53 in A375-S2 melanoma cells $(9,10)$. In HepG2 hepatoma cells, evodiamine results in cell death by reducing $\mathrm{Bcl} 2 / \mathrm{Bax}$ ratio (11). Although it was presented that 

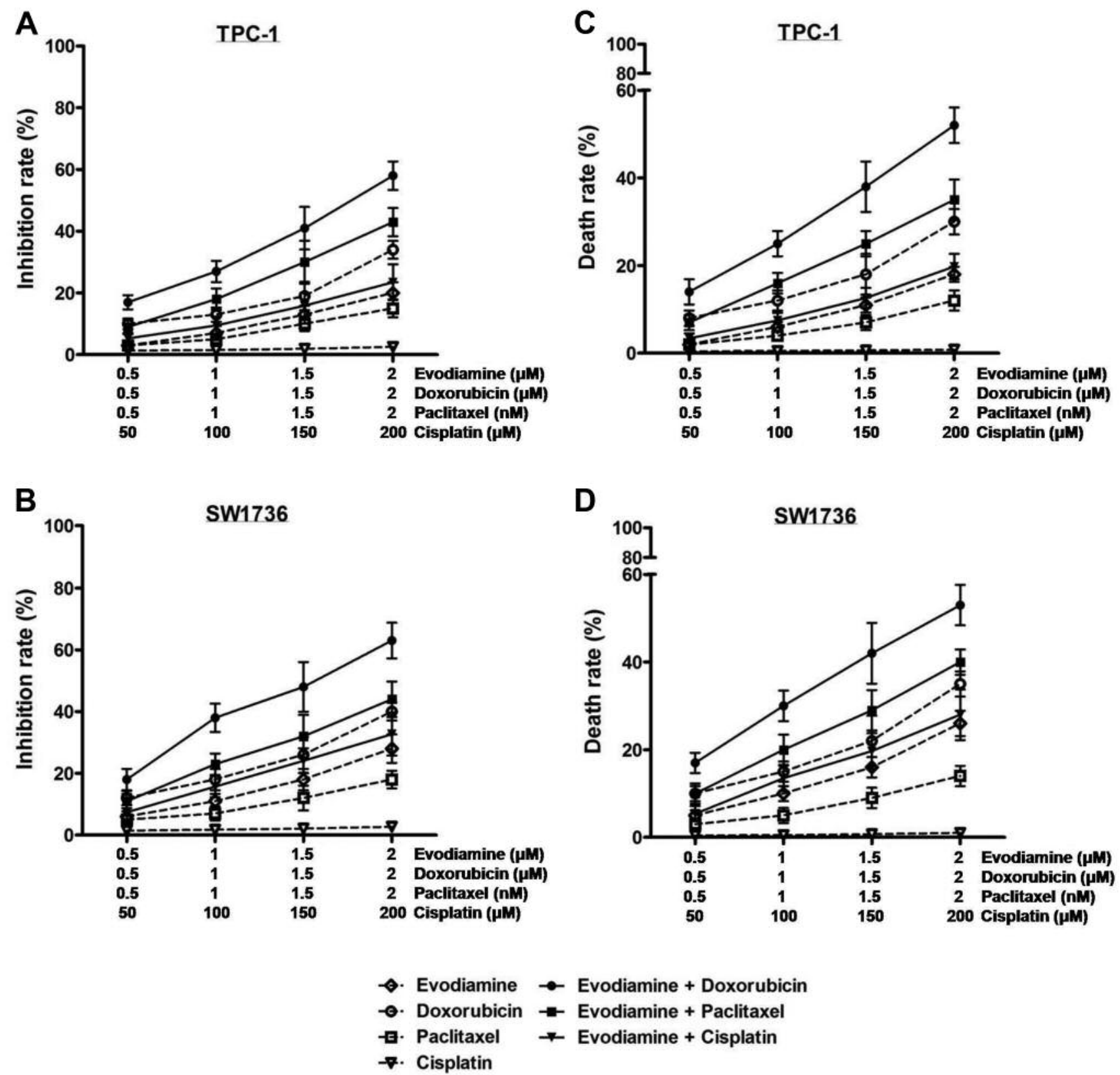

Figure 5. The influence of the combination of evodiamine with chemotherapeutic agents on growth and survival of thyroid carcinoma cells. TPC-1 and SW1736 cells were treated with both 0.5, 1, 1.5, $2 \mu \mathrm{M}$ evodiamine and 0.5, 1, 1.5, $2 \mu \mathrm{M}$ doxorubicin, 0.5, 1, 1.5, 2 nM paclitaxel or 50, 100, 150, $200 \mu \mathrm{M}$ cisplatin for $24 \mathrm{~h}$. A and B: Cell growth was measured assayed by using cell number count, and the inhibition rate was calculated as 100-cell growth (\%). C and D: Cell viability was measured using CCK-8 assay, and the death rate was computed as 100-cell viability (\%). Combination index and isobologram were estimated. All experiments were performed in triplicate. Data are expressed as mean \pm S.E.

evodiamine inhibited survival and proliferation of ARO cells, thought to be ATC cells, the cells have been identified as colon cancer cells $(7,28)$. TPC-1 and SW1736 cells used in this study have been authenticated as PTC and ATC cells, respectively, and thus our findings are the first to report that evodiamine induces death of true thyroid carcinoma cells
(28). Briefly, evodiamine reduced cell viability, and elevated cytotoxic activity and the percentage of apoptotic cells in a dose-dependent manner. Correspondingly, evodiamine reduced $\mathrm{Bcl} 2$ protein levels, whereas it did not change Bax protein levels, causing reduction of $\mathrm{Bcl} 2 / \mathrm{Bax}$ ratio. In addition, evodiamine elevated the protein levels of $\gamma \mathrm{H} 2 \mathrm{AX}$ 
and cleaved PARP, and reduced those of survivin. These data indicate that evodiamine leads to cell death with concomitant alterations in expression of $\mathrm{Bcl} 2$, survivin and $\gamma \mathrm{H} 2 \mathrm{AX}$ in thyroid carcinoma cells. Furthermore, these results suggest that evodiamine exerts a cytotoxic activity through modulation of survival-related proteins in thyroid carcinoma cells. In this regard, further studies on clinical implications of evodiamine in thyroid cancer patients are necessary to examine whether cytotoxicity is reenacted in in vivo models.

PI3K/AKT signaling orchestrates many intracellular processes essential for survival of healthy cells (29). In thyroid carcinoma cells, it has been shown that aberrant activation of PI3K/AKT signaling participates in neoplastic transformation, and PI3K/AKT signaling plays pivotal roles in cell survival in our previous reports (30-37). With respect to the involvement of PI3K/AKT signaling in evodiamineinduced antitumor action, it has been shown that evodiamine enhances the therapeutic efficacy of gemcitabine via direct or indirect negative regulation of $\mathrm{PI} 3 \mathrm{~K} / \mathrm{AKT}$ signaling in in vitro and in vivo models of pancreatic cancer (12). Moreover, evidence has been provided clarifying that evodiamine results in cell death by diminishing phospho-AKT protein levels in HepG2 hepatoma cells, and represses cell proliferation through inactivation of PI3K/AKT signaling and PTEN in osteosarcoma cells $(11,13)$. In A375-S2 melanoma cells, evodiamine causes cell death via diminution of PI3K/AKT signaling and enhancement of Fas-L/NF-KB signaling, and deactivation of $\mathrm{PI} 3 \mathrm{~K} /$ protein kinase $\mathrm{C}$ and ERK cascade with inactivation of SIRT1 $(9,10)$. In addition to PI3K/AKT signaling, evodiamine has anticancer action by modulating different signaling pathways such as NF-kB, mitogenactivated protein kinases and $\mathrm{Wnt} / \beta$-catenin $(8,14,15)$. In the present study, evodiamine enhanced the protein levels of phospho-JNK, and diminished those of phospho-AKT and phospho-NF-kB without affecting those of total AKT, total NF-kB, total JNK, and total and phospho-ERK1/2. However, in cells treated with evodiamine, the PI3K inhibitor wortmannin only, but not the inhibitors of NF-kB, JNK and ERK1/2, diminished cell viability, and enhanced cytotoxic activity. Furthermore, wortmannin enhanced the protein levels of cleaved PARP, and diminished those of phospho-AKT and Bcl2 without affecting those of total AKT and Bax. These findings manifest that suppression of AKT stimulates cell death induced by evodiamine in thyroid carcinoma cells. Considering our previous studies verifying that inhibition of AKT intensifies the cytotoxic activity of various agents in thyroid carcinoma cells (38-40), the results of this study imply that repression of AKT reinforces evodiamine-induced cytotoxicity in thyroid carcinoma cells.

The p21, p53 and matrix metalloproteinases are related to proliferation, migration, invasion and metastasis of cancer cells (41-43). In this regard, we have previously reported that p21, p53, MMP-2 and MMP-9 are responsible for proliferation and migration of thyroid carcinoma cells (37, 44). Besides its cytostatic and cytotoxic effects, evodiamine impedes cancer progression through interruption of migration, invasion and metastasis of cancer cells $(5,16)$. In in vitro and in vivo studies, it has been shown that evodiamine suppresses cell migration and invasion via MMP-2 and MMP-9 in prostate and nasopharyngeal cancer cells, and decreases metastatic foci in colon cancer cell-inoculated nude mice (1719). With respect to EMT, evodiamine has been documented to inactivate bioactive HGF, and thereby inhibit HGFstimulated invasiveness in melanoma, lung and colon cancer cells (20). Moreover, evodiamine lessens self-renewal by ameliorating EMT in a process of canonical Wnt/ $\beta$-catenin signaling in gastric cancer stem cells, and exhibits a repressive property on TGF- $\beta$-stimulated EMT in NRK52E cells and liver fibrosis in rats $(15,21,22)$. In the present study, evodiamine decreased cell growth and migration in conjunction with increment of the protein levels of p21 and p53 as well as decrement of those of MMP-2 and MMP-9. TGF- $\beta$ accelerated cell growth and migration, and induced a fibroblast-like phenotype, while evodiamine abolished the TGF- $\beta$-induced changes in cell growth, morphology and migration. In TGF- $\beta$-treated cells, the protein levels of $\mathrm{N}$-cadherin, phospho-AKT and MMP-2 increased, and those of p21 and p53 decreased but those of $\beta$-catenin, vimentin, slug, total AKT and MMP-9 were not altered. In cells treated with both evodiamine and TGF- $\beta$, compared with TGF- $\beta$ alone, the protein levels of p21 and p53 increased, and those of $\beta$-catenin, $\mathrm{N}$-cadherin, vimentin, phospho-AKT, MMP-2 and MMP-9 decreased, whereas those of slug and total AKT were unchanged. Taken together, these data reveal that evodiamine mitigates cell proliferation and migration with concomitant overexpression of p21 and p53 as well as underexpression of $\beta$-catenin, $\mathrm{N}$-cadherin, vimentin, phosphoAKT, MMP-2 and MMP-9 in TGF- $\beta$-treated thyroid carcinoma cells. In addition, these results suggest that evodiamine negatively affects TGF- $\beta$-induced EMT of thyroid carcinoma cells through regulation of EMT-related proteins.

In the national guidelines, it is recommended that chemotherapeutic agents may be considered in tyrosine kinase inhibitor-refractory WDTC and ATC patients $(2,3)$. In this regard, doxorubicin has been approved as monotherapy, but its clinical efficacy and response are not satisfactory in ATC patients (45). Furthermore, it has been reported that doxorubicin fails to eliminate cancer stem cells derived from ATC cells (46). With respect to other chemotherapeutic agents, paclitaxel was shown to be a more beneficial chemotherapeutic agent than those traditionally used in ATC patients but we have reported that the heat shock protein 90 inhibitor 17-allylamino17-demethoxygeldanamycin antagonizes with paclitaxel in inducing death of ATC cells $(32,47)$. Moreover, cisplatin alone or in combination with docetaxel was shown to have an influence on ATC patients $(3,48)$. In view of the combination 
of evodiamine with chemotherapeutic agents, evodiamine induces cell death in chemoresistant breast cancer in vitro and in vivo models $(23,24)$. In addition, evodiamine leads to cytostatic and cytotoxic action in A2780 ovarian cancer cells refractory to paclitaxel (25). In the present study, when evodiamine was combined with the chemotherapeutic agents doxorubicin, paclitaxel or cisplatin, all CI values were lower than 1.0 in terms of inhibition and death rates. These findings demonstrate that evodiamine has a synergistic activity with doxorubicin, paclitaxel or cisplatin in suppressing growth and survival of thyroid carcinoma cells. Furthermore, these results imply that evodiamine acts synergistically with chemotherapeutic agents to induce cytostasis and cytotoxicity in thyroid carcinoma cells. Therefore, combination of evodiamine with chemotherapeutic agents may be an attractive therapeutic regimen in human thyroid cancer.

In conclusion, our results suggest that evodiamine poses antioncogenic action by modulating survival-related proteins, and inhibition of AKT magnifies evodiamine-induced cytotoxic activity in thyroid carcinoma cells. Moreover, evodiamine abrogates proliferation, migration and EMT by regulating EMTrelated proteins, and synergizes with chemotherapeutic agents in inducing cytostasis and cytotoxicity in thyroid carcinoma cells. Although our data should be scrutinized in an in vivo model, this study implies that evodiamine alone or in combination with chemotherapeutic agents is a promising remedy in thyroid cancer patients resistant to conventional approaches.

\section{Acknowledgements}

This work was supported by the National Research Foundation of Korea (NRF) grant funded by the Korea government (MSIP) (No. 2018R1D1A1B07044901) to S.J. Lee, Republic of Korea, and was also supported by Hallym University Research Fund to S.J. Lee, Republic of Korea.

\section{References}

1 Nervo A, Gallo M, Samà MT, Felicetti F, Alfano M, Migliore E, Marchisio F, Berardelli R, Arvat E and Piovesan A: Lenvatinib in advanced radioiodine-refractory thyroid cancer: a snapshot of real-life clinical practice. Anticancer Res 38: 1643-1649, 2018.

2 Haugen BR, Alexander EK, Bible KC, Doherty GM, Mandel SJ, Nikiforov YE, Pacini F, Randolph GW, Sawka AM, Schlumberger M, Schuff KG, Sherman SI, Sosa JA, Steward DL, Tuttle RM and Wartofsky L: 2015 American Thyroid Association management guidelines for adult patients with thyroid nodules and differentiated thyroid cancer: the American Thyroid Association guidelines task force on thyroid nodules and differentiated thyroid cancer. Thyroid 26: 1-133, 2016.

3 Smallridge RC, Ain KB, Asa SL, Bible KC, Brierley JD, Burman KD, Kebebew E, Lee NY, Nikiforov YE, Rosenthal MS, Shah MH, Shaha AR and Tuttle RM: American Thyroid Association guidelines for management of patients with anaplastic thyroid cancer. Thyroid 22: 1104-1139, 2012
$4 \mathrm{Yu} \mathrm{H}$, Jin $\mathrm{H}$, Gong W, Wang $\mathrm{Z}$ and Liang H: Pharmacological actions of multi-target-directed evodiamine. Molecules 18: 1826$1843,2013$.

5 Jiang J and Hu C: Evodiamine: a novel anti-cancer alkaloid from Evodia rutaecarpa. Molecules 14: 1852-1859, 2009.

6 Zhang C, Fan X, Xu X, Yang X, Wang X and Liang HP: Evodiamine induces caspase-dependent apoptosis and $\mathrm{S}$ phase arrest in human colon lovo cells. Anticancer Drugs 21: 766-776, 2010.

7 Chen MC, Yu CH, Wang SW, Pu HF, Kan SF, Lin LC, Chi CW, Ho LL, Lee $\mathrm{CH}$ and Wang PS: Anti-proliferative effects of evodiamine on human thyroid cancer cell line ARO. J Cell Biochem 110: 1495-1503, 2010.

8 Takada Y, Kobayashi Y and Aggarwal BB: Evodiamine abolishes constitutive and inducible NF-kappaB activation by inhibiting IkappaBalpha kinase activation, thereby suppressing NF-kappaBregulated antiapoptotic and metastatic gene expression, upregulating apoptosis, and inhibiting invasion. J Biol Chem 280: 17203-17212, 2005.

9 Wang C, Li S and Wang MW: Evodiamine-induced human melanoma A375-S2 cell death was mediated by PI3K/Akt/ caspase and Fas-L/NF-kappaB signaling pathways and augmented by ubiquitin-proteasome inhibition. Toxicol In Vitro 24: 898-904, 2010.

10 Wang C, Wang MW, Tashiro S, Onodera S and Ikejima T: Roles of SIRT1 and phosphoinositide 3-OH kinase/protein kinase C pathways in evodiamine-induced human melanoma A375-S2 cell death. J Pharmacol Sci 97: 494-500, 2005.

11 Yang F, Shi L, Liang T, Ji L, Zhang G, Shen Y, Zhu F and Xu L: Anti-tumor effect of evodiamine by inducing Akt-mediated apoptosis in hepatocellular carcinoma. Biochem Biophys Res Commun 485: 54-61, 2017.

12 Wei WT, Chen H, Wang ZH, Ni ZL, Liu HB, Tong HF, Guo HC, Liu DL and Lin SZ: Enhanced antitumor efficacy of gemcitabine by evodiamine on pancreatic cancer via regulating PI3K/Akt pathway. Int J Biol Sci 8: 1-14, 2012.

13 Meng ZJ, Wu N, Liu Y, Shu KJ, Zou X, Zhang RX, Pi CJ, He BC, Ke ZY, Chen L, Deng ZL and Yin LJ: Evodiamine inhibits the proliferation of human osteosarcoma cells by blocking PI3K/Akt signaling. Oncol Rep 34: 1388-1396, 2015.

14 Chien CC, Wu MS, Shen SC, Ko CH, Chen CH, Yang LL and Chen YC: Activation of JNK contributes to evodiamine-induced apoptosis and $\mathrm{G}_{2} / \mathrm{M}$ arrest in human colorectal carcinoma cells: a structure-activity study of evodiamine. PLoS One 9: e99729, 2014.

15 Wen Z, Feng S, Wei L, Wang Z, Hong D and Wang Q: Evodiamine, a novel inhibitor of the Wnt pathway, inhibits the self-renewal of gastric cancer stem cells. Int J Mol Med 36: $1657-1663,2015$.

16 Fei XF, Wang BX, Li TJ, Tashiro S, Minami M, Xing DJ and Ikejima T: Evodiamine, a constituent of Evodiae Fructus, induces anti-proliferating effects in tumor cells. Cancer Sci 94: 92-98, 2003.

17 Chang WL, Yu CC, Chen CS and Guh JH: Tubulin-binding agents down-regulate matrix metalloproteinase-2 and -9 in human hormone-refractory prostate cancer cells - a critical role of Cdk1 in mitotic entry. Biochem Pharmacol 94: 12-21, 2015.

18 Peng X, Zhang Q, Zeng Y, Li J, Wang L and Ai P: Evodiamine inhibits the migration and invasion of nasopharyngeal carcinoma cells in vitro via repressing MMP-2 expression. Cancer Chemother Pharmacol 76: 1173-1184, 2015. 
19 Ogasawara M, Matsubara T and Suzuki H: Inhibitory effects of evodiamine on in vitro invasion and experimental lung metastasis of murine colon cancer cells. Biol Pharm Bull 24: 917-920, 2001.

20 Ogasawara $M$ and Suzuki H: Inhibition by evodiamine of hepatocyte growth factor-induced invasion and migration of tumor cells. Biol Pharm Bull 27: 578-582, 2004.

21 Wei J, Li Z and Yuan F: Evodiamine might inhibit TGF-beta1induced epithelial-mesenchymal transition in NRK52E cells via Smad and PPAR-gamma pathway. Cell Biol Int 38: 875-880, 2014.

22 Yang D, Li L, Qian S and Liu L: Evodiamine ameliorates liver fibrosis in rats via TGF-beta1/Smad signaling pathway. J Nat Med 72: 145-154, 2018.

23 Wang S, Wang L, Shi Z, Zhong Z, Chen M and Wang Y: Evodiamine synergizes with doxorubicin in the treatment of chemoresistant human breast cancer without inhibiting Pglycoprotein. PLoS One 9: e97512, 2014.

24 Liao CH, Pan SL, Guh JH, Chang YL, Pai HC, Lin CH and Teng CM: Antitumor mechanism of evodiamine, a constituent from Chinese herb Evodiae fructus, in human multiple-drug resistant breast cancer NCI/ADR-RES cells in vitro and in vivo. Carcinogenesis 26: 968-975, 2005.

25 Zhong ZF, Tan W, Wang SP, Qiang WA and Wang YT: Antiproliferative activity and cell cycle arrest induced by evodiamine on paclitaxel-sensitive and -resistant human ovarian cancer cells. Sci Rep 5: 16415, 2015.

26 Cory S and Adams JM: The Bcl2 family: regulators of the cellular life-or-death switch. Nat Rev Cancer 2: 647-656, 2002.

27 Cory S and Adams JM: Killing cancer cells by flipping the Bcl2/Bax switch. Cancer Cell 8: 5-6, 2005.

28 Schweppe RE, Klopper JP, Korch C, Pugazhenthi U, Benezra M, Knauf JA, Fagin JA, Marlow LA, Copland JA, Smallridge RC and Haugen BR: Deoxyribonucleic acid profiling analysis of 40 human thyroid cancer cell lines reveals cross-contamination resulting in cell line redundancy and misidentification. J Clin Endocrinol Metab 93: 4331-4341, 2008.

29 Testa JR and Tsichlis PN: AKT signaling in normal and malignant cells. Oncogene 24: 7391-7393, 2005.

30 Xing M: Genetic alterations in the phosphatidylinositol-3 kinase/Akt pathway in thyroid cancer. Thyroid 20: 697-706, 2010.

31 Kim SH, Kang JG, Kim CS, Ihm S-H, Choi MG, Yoo HJ and Lee SJ: Hsp70 inhibition potentiates radicicol-induced cell death in anaplastic thyroid carcinoma cells. Anticancer Res 34: 48294837, 2014.

32 Kim SH, Kang JG, Kim CS, Ihm S-H, Choi MG, Yoo HJ and Lee SJ: The effect of 17-allylamino-17-demethoxygeldanamycin alone or in combination with paclitaxel on anaplastic thyroid carcinoma cells. Endocrine 48: 886-893, 2015.

33 Kim SH, Kang JG, Kim CS, Ihm S-H, Choi MG, Yoo HJ and Lee SJ: The novel heat shock protein 90 inhibitor NVP-AUY922 synergizes with the histone deacetylase inhibitor PXD101 in induction of death of anaplastic thyroid carcinoma cells. J Clin Endocrinol Metab 100: E253-E261, 2015.

$34 \mathrm{Kim}$ SH, Kang JG, Kim CS, Ihm S-H, Choi MG, Yoo HJ and Lee SJ: The heat shock protein 90 inhibitor SNX5422 has a synergistic activity with histone deacetylase inhibitors in induction of death of anaplastic thyroid carcinoma cells. Endocrine 51: 274-282, 2016.

35 Kim SH, Kang JG, Kim CS, Ihm S-H, Choi MG, Yoo HJ and Lee SJ: Synergistic cytotoxicity of BIIB021 with triptolide through suppression of PI3K/Akt/mTOR and NF-kB signal pathways in thyroid carcinoma cells. Biomed Pharmacother 83: 22-32, 2016.

36 Kim SH, Kang JG, Kim CS, Ihm S-H, Choi MG, Yoo HJ and Lee SJ: Gemigliptin, a novel dipeptidyl peptidase-IV inhibitor, exerts a synergistic cytotoxicity with the histone deacetylase inhibitor PXD101 in thyroid carcinoma cells. J Endocrinol Invest 41: 677$689,2018$.

37 Kim YJ, Hwang H-J, Kang JG, Kim CS, Ihm S-H, Choi MG and Lee SJ: Enigma plays roles in survival of thyroid carcinoma cells through PI3K/AKT signaling and survivin. Anticancer Res 38: 3515-3525, 2018.

38 Kim SH, Kang JG, Kim CS, Ihm S-H, Choi MG, Yoo HJ and Lee SJ: Akt inhibition enhances the cytotoxic effect of apigenin in combination with PLX4032 in anaplastic thyroid carcinoma cells harboring BRAFV600E. J Endocrinol Invest 36: 1099-1104, 2013.

39 Kim SH, Kang JG, Kim CS, Ihm S-H, Choi MG, Yoo HJ and Lee SJ: Inhibition of p21 and Akt potentiates SU6656-induced caspase-independent cell death in FRO anaplastic thyroid carcinoma cells. Horm Metab Res 45: 408-414, 2013.

40 Kim SH, Kang JG, Kim CS, Ihm S-H, Choi MG, Yoo HJ and Lee SJ: Suppression of AKT potentiates synergistic cytotoxicity of apigenin with TRAIL in anaplastic thyroid carcinoma cells. Anticancer Res 35: 6529-6537, 2015.

41 Abbas T and Dutta A: p21 in cancer: intricate networks and multiple activities. Nat Rev Cancer 9: 400-414, 2009.

42 Pietsch EC, Sykes SM, McMahon SB and Murphy ME: The p53 family and programmed cell death. Oncogene 27: 6507-6521, 2008.

43 Roomi MW, Monterrey JC, Kalinovsky T, Rath M and Niedzwiecki A: Patterns of MMP-2 and MMP-9 expression in human cancer cell lines. Oncol Rep 21: 1323-1333, 2009.

44 Kim SH, Kang JG, Kim CS, Ihm S-H, Choi MG, Yoo HJ and Lee SJ: Synergistic cytotoxicity of the dipeptidyl peptidase-IV inhibitor gemigliptin with metformin in thyroid carcinoma cells. Endocrine 59: 383-394, 2018.

45 Haddad RI, Lydiatt WM, Ball DW, Busaidy NL, Byrd D, Callender G, Dickson P, Duh Q-Y, Ehya H, Haymart M, Hoh C, Hunt JP, Iagaru A, Kandeel F, Kopp P, Lamonica DM, McCaffrey JC, Moley JF, Parks L, Raeburn CD, Ridge JA, Ringel MD, Scheri RP, Shah JP, Smallridge RC, Sturgeon C, Wang TN, Wirth LJ, Hoffmann KG and Hughes M: Anaplastic thyroid carcinoma, version 2. Natl Compr Canc Netw 13: 1140-1150, 2015.

46 Zheng X, Cui D, Xu S, Brabant G and Derwahl M: Doxorubicin fails to eradicate cancer stem cells derived from anaplastic thyroid carcinoma cells: characterization of resistant cells. Int $\mathrm{J}$ Oncol 37: 307-315, 2010.

47 Ain KB, Egorin MJ and DeSimone PA: Treatment of anaplastic thyroid carcinoma with paclitaxel: phase 2 trial using ninety-sixhour infusion. Collaborative Anaplastic Thyroid Cancer Health Intervention Trials (CATCHIT) Group. Thyroid 10: 587-594, 2000.

48 Seto A, Sugitani I, Toda K, Kawabata K, Takahashi S and Saotome T: Chemotherapy for anaplastic thyroid cancer using docetaxel and cisplatin: report of eight cases. Surg Today 45: 221-226, 2015 